\title{
Malgorzata Kierat*
}

Uniwersytet Śląski w Katowicach

\section{KRÓTKA HISTORIA DŁUGIEJ PRZYJAŹNI, CZYLI O KORESPONDENCJI ALFREDA SCHÜTZA I ERICA VOEGELINA}

A Friendship That Lasted a Lifetime. The correspondence between Alfred Schütz and Eric Voegelin, 2011. Gerhard Wagner and Gilbert Weiss (eds), przeł. W. Petropulos, Eric Voegelin Institute Series.

A Friendship That Lasted a Lifetime jest dość obszernym zbiorem selektywnie wybranej korespondencji dwojga uczonych: Alfreda Schütza, socjologa, twórcy socjologii fenomenologicznej oraz Erica Voegelina, filozofa politycznego o szerokich zainteresowaniach historycznych i czołowego przedstawiciela myśli konserwatywnej, obnażającego mechanizmy tworzenia się dyktatur.

Zbiór ten został utworzony przez dwóch niemieckojęzycznych naukowców: profesora socjologii Gerharda Wagnera, pracującego na Uniwersytecie Goethego we Frankfurcie oraz salzburskiego wykładowcę w dziedzinie nauk politycznych - Gilberta Weissa. Obaj naukowcy dokonali wyboru i opracowania tych listów na podstawie jednego zasadniczego kryterium, a mianowicie: ich wkładu w rozwój myśli teoretycznej Schütza i Voegelina. Zatem zaprezentowana w tej publikacji korespondencja może być uznana za najistotniejszą ze względu na jej wpływ na osiagnięcia naukowo-badawcze obu tych uczonych, którzy - pomimo zmiennych kolei losu - przez ponad dwadzieścia lat prowadzili ten wyjątkowy dialog. Zarówno bowiem Schütz, jak i Voegelin zmuszeni do emigracji z rodzimej Austrii w 1938 roku znaleźli schronienie w Stanach Zjednoczonych, jednakże w ośrodkach uniwersyteckich znacznie oddalonych od siebie (Voegelin w Baton Rouge - stolicy stanu Luizjana, a Schütz w Nowym Jorku). Z tego powodu, pomimo okresowo osobistych spotkań, komunikowali się głównie listownie.

* Adres do korespondencji: Anna Kierat, Uniwersytet Śląski w Katowicach, Wydział Nauk Społecznych, ul. Bankowa 12, 40-007 Katowice, e-mail: malgorzata.kierat@wp.pl. 
Celem tej trwającej od 1938 do 1959 roku korespondencji była przede wszystkim wzajemna wymiana poglądów i stanowisk w zakresie obejmującym ich zainteresowania naukowo-badawcze oraz krytyczna analiza przesyłanych sobie fragmentów książek. Niemniej jednak tematyka tych listów obejmuje bardzo różnorodne dziedziny: także te dotyczące ich życia prywatnego oraz problemów dnia codziennego.

Liczba wszystkich dostępnych obecnie listów obu uczonych wynosi 238, jednak w wymienionym przeze mnie zbiorze (a jest to pierwsze wydanie w języku angielskim) zawartych jest ich mniej: tylko 88. Sama książka natomiast, z racji swojego charakteru, nie jest podzielona tradycyjnie na rozdziały, a zawiera jedynie chronologicznie uporządkowane i kolejno ponumerowane listy obu tych uczonych do siebie. Tam, gdzie poruszają oni szczególnie ważne dla ich dorobku naukowego kwestie, listy są prezentowane jeden po drugim, co oznacza, że w danym temacie (np.: zagadnienia związane z pojęciem gnozy lub krytyka niektórych poglądów Maxa Webera) ta część korespondencji jest kompletna.

Cenną pomoca, jeśli chodzi o orientację czytelnika w treści całej korespondencji, jest zamieszczony z tyłu publikacji załącznik zawierający kompletny spis listów Alfreda Schütza i Erica Voegelina. Załącznik ten zawiera krótkie, zwykle jednozdaniowe streszczenia tych listów, które nie zostały zawarte w recenzowanej tu książce. Pozwala to czytelnikowi na kompleksowe zapoznanie się z przebiegiem całej tej korespondencyjnej relacji, a nie tylko z jej obszernymi fragmentami występującymi w formie kompletnych listów znajdujących się w tym wydaniu. Najistotniejszą jednak wartością tej książki jest, jak się wydaje, fakt, że ukazuje ona wielopłaszczyznowość dialogu uczonych. Nie sposób bowiem pominąć wpływu, które owe korespondencyjne przemyślenia Schütza i Voegelina miały na rozwój ich własnych interpretacji rzeczywistości, określenie hierarchii wartości w odniesieniu do innych ludzi, na umiejętności krytycznej analizy oraz samooceny własnych poglądów.

Z publikacji tej wyłania się portret Voegelina jako nie tylko - jak zwykli go określać niektórzy - tropiciela wszelkich przejawów gnozy w polityce, ale również wyjątkowo płodnego intelektualnie i wszechstronnie wykształconego humanisty. Jego listy, zwykle dość obszerne, napisane zostały bowiem nie tylko stylem przepełnionym wielką pasją, ale i dogłębną znajomością tematu. Na szczególną uwagę wydają się w tym kontekście zasługiwać niektóre, szczególnie ważne, wątki tych listów.

Jednym z nich jest krytyka poglądów Edmunda Husserla dotycząca zbytniej, zdaniem Voegelina, koncentracji tego filozofa na zagadnieniach związanych $\mathrm{z}$ epistemologią. $\mathrm{W}$ tym liście Voegelin wyraża także swoje rozczarowanie innymi dziełami Husserla, nie odmawiając im jednak znaczącego wkładu w rozwój krytyki epistemologicznej (list nr 15, s. 30 ).

Kolejne ważne listy zawierają rozważania na temat starożytnych filozofów oraz uwagi o ,porządku duszy” i ,porządku dominacji” (list nr 53, s. 129), a także spostrzeżenia na temat relacji pomiędzy chrześcijaństwem a filozofią i odniesienia do Platona, Karola Marksa, Immanuela Kanta (list nr 66, s. 171). Warto wspomnieć w tym miejscu, że uczony twierdzi wprost w tym liście, że to nie pobudki osobiste skłoniły go do gruntowego poznania religii chrześcijańskiej, ale fakt, iż - jego zdaniem - żaden badacz nie może przejść obojętnie nad ponadtysiącletnim związkiem myśli chrześcijańskiej z życiem politycznym jednostek i narodów. Oznacza to dla Voegelina, że fenomen tego związku powinien być traktowany 
przez historię idei z zachowaniem tych samych rygorystycznych zasad, które obowiązują w przypadku na przykład filozofii Platona czy Hegla (list nr 66, s. 171).

Z kolei nawiązując dalej w wyżej wymienionym liście do swoich rozważań poświęconych chrześcijaństwu, Voegelin podkreśla kilkakrotnie uniwersalne i ponadczasowe przesłanie tej religii. Sam Bóg bowiem, zdaniem uczonego, w swoim monoteistycznym sensie, przejawia się jako idea radykalnie uniwersalna dla wszystkich ludzi.

Bardzo szeroka wiedza z zakresu filozofii, historii, religii oraz idei politycznej Voegelina zaowocowała, co również należy w tym miejscu zaznaczyć, najbardziej obszerną i najlepiej chyba znaną publikacją jego życia. Chodzi tu o wielotomowe dzieło pt.: History of Political Ideas, o którym mowa w recenzowanej tu książce wielokrotnie. Voegelin także jako wytrawny znawca historii idei obnaża wszelkie poglądy nawiązujące do ideologii faszystowskiej. Poza tym w listach do swojego przyjaciela nie ukrywa własnego uznania dla filozofii Platona, którego uważa za najwybitniejszego z filozofów. Voegelin jednakże jest - przede wszystkim - wytrawnym znawcą koncepcji gnozy politycznej, która, od kiedy uległa sekularyzacji, jest - według niego - prawdziwym zagrożeniem dla współczesnych społeczeństw (np.: tłumaczy on na jej podstawie sukces polityczny faszyzmu).

Ważną postacią przewijającą się często w opisywanej tu korespondencji jest bliska obojgu uczonym osoba Edmunda Husserla, twórcy fenomenologii. Z tego powodu wiele wcześniejszych listów zawartych w tej książce nawiązuje do tego filozofa. Dzieje się to, na przykład, dzięki obronie Husserla (autora dzieła pt.: Kryzys nauk europejskich i fenomenologia transcendentalna) przez Voegelina przed zarzutami pozytywistów, ale też przez, na przykład, porównanie go do Kanta, który (podobnie jak Husserl) wierzy - zdaniem Voegelina niesłusznie - w stały postęp ludzkiego rozumu. Voegelin zresztą wydaje się znacznie bardziej krytyczny wobec Husserla niż Schütz. Ten z kolei chętnie dzieli się ze swoim przyjacielem przemyśleniami na temat transcendentalnego subiektywizmu Husserla, którego krytykę zawarł w jednym ze swoich esejów. Voegelin stwierdza natomiast, w jednym z listów do przyjaciela, że Husserl nie poruszył w swoich dziełach wielu fundamentalnych dla filozofii tematów, które zresztą, zdaniem Schütza, nie dadzą się badać przy wykorzystaniu tak zwanych metod ściśle naukowych, co powoduje konieczność zdobycia się na odwagę zagłębienia się w tajemnicę metafizyki (list nr 23, s. 50). Poza tym Schütz stara się znaleźć argumenty, które przekonałyby Voegelina do mniej krytycznej oceny dzieła Husserla. Ponadto w swoich listach do Voegelina wydaje się on mieć czasami problemy z terminologią używaną przez autora History of Political Ideas, stąd też prosi o jej doprecyzowanie. Dzieje się tak chociażby ze znanym i często przytaczanym terminem Voegelina, określanym przez niego jako leap in being (skok w bycie). Schütz kilka razy prosi o dokładniejsze wyjaśnienie tego pojęcia.

Poza tematami ściśle naukowymi uczeni poruszają również problemy dnia codziennego, jak - na przykład - problemy z własnym zdrowiem, formy pomocy swoim rodzinom (teściowie Voegelina przebywali podczas wojny w obozie koncentracyjnym, zaś cała dalsza rodzina Schütza zginęła podczas wojny); dyskutują o specyfice swoich środowisk akademickich oraz trudnościach z aklimatyzacją w nowych dla nich otoczeniach i odmiennej kulturze. Tę długoletnią przyjaźń obu uczonych oraz ich wieloletnią wymianę listów kończy śmierć Schütza w 1959 roku. 
Jeśli natomiast chodzi o listy Schütza do Voegelina, to prawdopodobnie najistotniejsze z nich to: list zawierający uwagi krytyczne co do spisu treści książki Voegelina pt.: History of Political Ideas (list nr 35, s. 90), podziękowanie za uwagi krytyczne na temat swojej książki pt.: On Multiple Realities (list nr 39, s. 105) oraz list omawiający fragmenty książki Voegelina pt.: New Science of Politics (list nr 65, s. 155).

Starając się zrozumieć wagę tej korespondencji w twórczym procesie naukowo-badawczym, nie sposób nie dostrzec, że najcenniejszą funkcją - w sensie formacji intelektualnej obu tych humanistów - były ich pytania do siebie nawzajem, a także prośby o wyjaśnienia terminologii i uwagi krytyczne. Pełniąc dla siebie nawzajem role autorytetów dokonujących życzliwej i uważnej krytyki, kształtowali oni obaj własne teorie naukowe w odniesieniu do punktu widzenia przyszłego czytelnika. Niewątpliwie więc dorobek naukowy obu tych uczonych na tym zyskał, co jednak nie oznacza, że w takim samym stopniu. Wnikliwemu czytelnikowi trudno bowiem będzie oprzeć się wrażeniu, że to Voegelin był większym beneficjentem tej szczególnej korespondencji, gdyż to właśnie on był zmuszony przez swojego przyjaciela do sprostania większej liczbie pytań i wątpliwości. To oczywiście zmuszało go do jeszcze bardziej wytężonej pracy nad argumentacją logiczną stawianych przez siebie tez i bardziej klarownym językiem swoich wywodów.

Najlepiej zresztą obrazują owe poszukiwania słowa samego Voegelina, które wypowiedział on po śmierci Schütza, a brzmiały one następująco: „Niemal cztery dekady wzajemnego dzielenia się własnymi przemyśleniami oraz wymiana krytycznych ocen nie tylko pozostawiły ślad na moim własnym dorobku, ale wytworzyły nawyk zadawania pytań samemu sobie z perspektywy tego dorobku; pytań o to, co ta druga strona pomyślałaby o nim. Jeden z najbardziej twórczych w sensie filozoficznym umysłów naszych czasów [czyli Schütz - przyp. M.K.] jest nadal milczącym towarzyszem moich myśli” (ze wstępu, s. 3).

Publikacja ta to szczególny rodzaj książki. Zaprasza czytelnika do wsłuchania się w niecodzienną, trwającą aż dwadzieścia jeden lat rozmowę dwóch ważnych dla współczesnej filozofii polityki i socjologii uczonych. Jej największą zaletą, oprócz bardzo trafnie oraz umiejętnie wyselekcjonowanej korespondencji oraz bardzo starannego jej opracowania, jest to, że daje czytelnikowi możliwość bezpośredniego uczestnictwa w procesie formowania się i ewolucji poglądów naukowych Voegelina i Schütza, a nie tylko ich ostateczny rezultat, którego ów czytelnik mógłby być jedynie biernym odbiorcą.

Książka A Friendship That Lasted a Lifetime jest więc cenną publikacją godną polecenia czytelnikom zainteresowanym filozofią polityczną i socjologią fenomenologiczną, a wręcz niezbędną, by uzyskać wgląd w twórczy proces będący ilustracją logiki i historii dochodzenia do prawdy naukowej wybitnych uczonych XX wieku zmagających się w klasycznym dialogu $\mathrm{z}$ fundamentalnymi pytaniami o ład społeczny dziejów. 